University of Rhode Island

DigitalCommons@URI

Open Access Master's Theses

1992

\title{
Preserving Rural Landscape in the Midst of Suburban Sprawl
}

James Gregory Duncan

University of Rhode Island

Follow this and additional works at: https://digitalcommons.uri.edu/theses

\section{Recommended Citation}

Duncan, James Gregory, "Preserving Rural Landscape in the Midst of Suburban Sprawl" (1992). Open Access Master's Theses. Paper 747.

https://digitalcommons.uri.edu/theses/747

This Thesis is brought to you for free and open access by DigitalCommons@URI. It has been accepted for inclusion in Open Access Master's Theses by an authorized administrator of DigitalCommons@URI. For more information, please contact digitalcommons-group@uri.edu. 


\title{
PRESERVING RURAL LANDSCAPE
}

IN THE MIDST OF SUBURBAN SPRAWL

$$
\text { BY }
$$

JAMES GREGORY DUNCAN

\author{
A RESEARCH PROJECT SUBMTTTED IN \\ PARTIAL FULFILLMENT OF THE REQUIREMENTS \\ FOR THE DEGREE OF MASTER OF \\ COMMUNITY PLANNING
}

UNIVERSITY OF RHODE ISLAND

1992 


\section{MASTER OF COMMUNITY PLANNING \\ RESEARCH PROJECT \\ OF}

JAMES GREGORY DUNCAN

Approved:

Major Professor

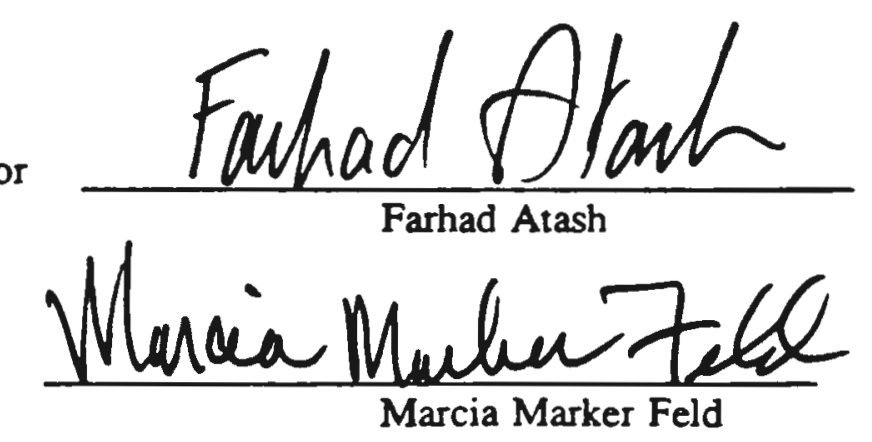

Acknowledged:

Director 


\section{Acknowledgements}

There are many people I wish to acknowledge for their role in the development of this project and my overall exposure to planning. First, I would like to thank Dr. Farhad Atash for his assistance in making my project worthwhile and beneficial to me and hopefully anyone who reads it. Thanks to Dr. John Kupa for making me appreciate the environment, and for being a guiding force in my decision to go into planning. I am grateful to Kevin Flynn for his guidance in applying this project to the City of Cranston, for giving me a realistic view of the world, and for always providing me with a job. I would also like to express my gratitude to $\mathrm{Dr}$. Howard Foster for his expertise and for giving me the opportunity to enlighten the undergraduates.

Special thanks to my family, close friends, and all others who have had an impact on the person that I am (especially Paige). You deserve most of the credit for all of my achievements throughout the years. 


\begin{abstract}
Communities with rural settings are often subject to development pressures exerted by factors like suburban sprawl and infrastructure improvements. Communities that contain both urban and rural characteristics, or "bifurcated communities", must be able to control what types of development occur and to what degree, in their undeveloped areas. In doing so they are able to efficiently protect natural resources and the health, safety, and welfare of their residents.

This project will compile techniques designed to preserve the landscape of rural areas that are subject to development that occurs naturally and as a result of attempts to provide services to residents. Recommendations will then be made for application in the City of Cranston, Rhode Island. This information will enable Cranston and other communities to be aware of the many innovative measures that can be used to ensure that development occurs in an orderly, planned manner that reflects the community's desires.
\end{abstract}




\section{Table of Contents}

Acknowledgements

Abstract

List of Tables

i

ii

List of Figures

CHAPTER ONE - Introduction

Subject Statement

Subject Significance

Objectives

Procedures \& Methods of Analysis

Expected Outcomes

CHAPTER TWO - Ramifications of Suburban Sprawl on Rural Areas Introduction

Social Factors

Economic Factors

Demographic Factors

Physical Factors

Impacts of Sprawl

Fiscal Impacts

Social Impacts

Physical Impacts

Environmental Impacts

Conclusion

CHAPTER THREE - Rural Preservation Techniques for Communities

Agricultural Preservation Zoning

Cluster Development

Comprehensive Plan

Fee Simple Land Acquisition

Land Banking

Land Trust

Overlay District

Performance Zoning

Planned Unit Development

Purchase of Development Rights

Traditional Neighborhood District 
CHAPTER THREE (continued)

Transfer of Development Rights

Village Development

Conclusion

CHAPTER FOUR - Applications for the City of Cranston, Rhode Island Introduction

Government Structure

Growth Management Applications

Agricultural Preservation Zoning 51

Cluster Development 51

Comprehensive Plan 51

Fee Simple Land Acquisition $\quad 52$

Land Banking $\quad 52$

Land Trust 53

Overlay District 53

Performance Zoning 54

Planned Unit Development 54

Purchase of Development Rights 55

Special Permits $\quad 55$

Site Plan Review $\quad 56$

Traditional Neighborhood District $\quad 56$

Transfer of Development Rights $\quad 57$

Village Development $\quad 57$

Conclusion

CHAPTER FIVE - Expected Outcomes

Introduction

Education Techniques

Anton Nelessen

61

Andres Duany

62

Randall Arendt

62

Conclusion

$\begin{array}{ll}\text { BIBLIOGRAPHY } & 65\end{array}$

APPENDIX

City of Cranston Future Land Use Map 


\section{$\underline{\text { List of Tables }}$}

$\underline{\text { Table }}$

$\underline{\text { Page }}$

4.1 - Characteristics of Rural Preservation Techniques 


\section{List of Figures}

Figure $\quad \underline{\text { Page }}$

3.1 - Conventional versus Cluster Development 22

3.2 - Transfer of Development Rights 42

3.3 - Village Development 44

Appendix A - City of Cranston Future Land Use Map 67 


\section{CHAPTERONE}

Introduction

\section{Subject Statement}

Rural areas often lack adequate commercial and service facilities that offer basic goods and services to their residents. The installation and implementation of these facilities often requires an upgrading of the existing infrastructure. This can lead to activities, such as high density residential development, in the area which may be undesirable to local residents, and contrary to the usual activities that occur. Some examples are increased traffic congestion and high density development.

Suburban sprawl and increases or shifts in population often result in activities that cause net losses of open space that would have not occurred at normal development rates. They can also often lead to substantial alterations of rural landscape. While development in rural areas is often inevitable, it can take place in an orderly fashion that incorporates the existing landscape and other attributes into design. Despite this, in many instances it occurs on an unplanned, arbitrary basis. Methods designed to maintain the character of rural areas can be implemented in order to accomplish the goal of protecting the environmental qualities that have existed in these areas for centuries. Cities and towns can institute guidelines into their land use regulations that accomplish the goal of protecting natural resources such as scenic vistas and roads, vegetation, trees, groundwater and agricultural land. 
The City of Cranston, Rhode Island is an example of a city that must take action to preserve the rural setting of its westem section. Demographic analysis and aerial photography compiled from the Planning Department reveal two distinct sections which for the purpose of this project will be called the eastern and the western sections. The eastern section comprises a little less than half the land area and approximately $85 \%$ of the City's population, while the western section comprises about half of its land area and approximately $15 \%$ of its population.

A land use evaluation determined that only one commercial center exists, located in the northem part of the western section. Most residents must travel either into the eastern or northern sections of the City to acquire basic services such as convenience stores, gasoline stations, or dry cleaners. For reasons of convenience and safety, this creates a problem. In order to solve the problem, the draft Comprehensive Plan being produced by IEP Inc. of Northborough Massachusetts is suggesting as an altemative, the placement of one or more small commercial centers in strategically placed areas. Although this would solve the need for such services, the rural character of the area could change as a result if not properly implemented. Appendix A depicts Cranston's future land use as determined by IEP Inc. Preliminary interviews with city officials and residents of the westem section determined that there is a great desire to maintain the rural integrity of the area, but there is also a demand for more commercial and service functions as well as housing opportunities.

In the late 1970's the City decided to locate industrial uses in the northern part of the western section as a means of economic development taking advantage of an 
interchange of Interstate 295. Infrastructure improvements necessary for the types of industrial uses to be allowed, which included municipal and sewer extensions, were completed in 1981. The infrastructure extensions, in addition to the water service extensions completed to alleviate a well contamination problem, led to changes in the zoning regulations which allowed many high density ( $1 / 2$ acre lots) residential developments into the area over the last ten years. Since the majority of the zoning in this section was previously restricted to two acres, this was a dramatic change. Residents living in the southern part of the section are fearful that if commercial centers are allowed, the infrastrutural components required for these services may result in the same changes throughout the remainder of western Cranston. The Planning Director noted that the reason why most people moved into this section was because of the character of the area and the belief that it would never change (although they were by moving there, changing the character). ${ }^{1}$

Communities like Cranston, sometimes called "bifurcated communities", are special because they combine elements of both cities and towns. Because of its urban characteristics, such as infrastructure and proximity to highways and jobs, its rural areas have the potential for easy urbanization. If Cranston were primarily rural, without infrastructure, its landscape would not be in jeopardy of high density development because it would not be feasible. Because infrastructure stimulates the market for development, Cranston must institute controls which protect the rural resources of the community or they will ultimately vanish. The City is fortunate because it has the opportunity to transform the manner in which development takes place with the growth 
controls that exist today. This is something that many other cities have not been able to accomplish often resulting in undesirable conditions that do not promote the health, safety, and welfare of community residents.

The objectives of this project will be to identify methods of preserving the character of rural areas in cities and towns like Cranston, $\mathrm{RI}$ in the midst of development and infrastructure improvements, and once identified apply these methods to the City. An inventory of growth management techniques will be compiled consisting of the most appropriate methods that can be implemented in the case study and others like it.

\section{Subject Significance}

This study deals with researching methods designed to preserve the character of rural areas in the midst of sprawl and infrastructural improvements. This topic is directly relevant to planning because it deals with some of planning's basic premises. Planning is an ongoing attempt to guide future development and redevelopment of a neighborhood, community, or region in order to create and maintain a desirable environment and to promote the public health, safety, and welfare ${ }^{2}$. To plan is to formulate goals, and the means to achieve goals beforehand. Blind placement of activities without consideration of their impacts has been taking place for centuries. The results of these practices can be observed in almost every city. Many land use, transportation, housing, and environmental circumstances jeopardize the health, safety, and welfare of many residents of habitated areas. Because it is future oriented and comprehensive, planning seeks to improve the quality of public and private development that affects people and places. 
One of its underlying intents is to further the welfare of the people in communities by creating an increasingly better, more healthful, convenient, efficient, and attractive environment. This project is based on creating an environment that supports these characteristics through innovative land use and growth management strategies.

\section{Objectives}

In order to accomplish the goals of this project, certain objectives will be met. These objectives are listed below:

1) Determine if the character of all or some of the rural areas in cities and towns like Cranston remain constant despite infrastructure improvements;

2) Determine what techniques exist that are designed to preserve rural character of cities and towns; and

3) Determine which techniques would be best suited for Cranston, RI.

\section{Procedures and Methods of Analysis}

The following research design will outline the procedures and methods that will be implemented to analyze the data collected based on the major objectives of the project. These objectives have been reformulated into questions.

1. Determine if the character of rural areas in cities and towns like Cranston, RI remain constant despite infrastructure improvements.

Preliminary research has determined that in most cases infrastructure 
improvements are a direct cause of the development of land. The main infrastructure elements that are paramount to high density development (less than 20,000 square foot lots) are water supply and sewage treatment, exclusive of septic systems. Although the introduction of both of these services is the best scenario for high density development, the existence of either one spurs denser development to a greater extent than neither.

The main reason why density cannot occur at high levels without water or sewer services has to do with the natural methods of treating waste and obtaining drinking water. Large lots are necessary to ensure that the operation of septic systems do not contaminate drinking water wells. If both exist, the possibility of contamination is reduced, and therefore development can occur on smaller lots and areas can sustain more residential units. Commercial and industrial development may also result if sewer and water services are provided, however special considerations may apply to these categories and limit their development. Although high capacity transportation systems, electric, gas and other utilities are important, the existence of water and/or sewer exert the most powerful influence on an area's level of development.

2. Determine what techniques exist that are designed to preserve the rural character cities and towns.

The value of land and natural resources has increased as populations multiply and resources dwindle. This has caused planners, environmentalists, government officials, and citizens to become more involved in protecting these resources. As a result, efforts have been made to develop methods that protect the rural character and natural resources of areas. 
This movement towards resource protection has produced many ideas designed to meet preservation goals. Some examples include land trusts, overlay districts, fee simple land acquisition, performance zoning, transfer and purchase of development rights, land banking. It has also resurrected some old ideas. A recent movement called neotraditional town planning calls for planning to go back to its roots of early development and focuses more on the individual than the automobile. Neotraditionalism stresses the concepts of village and hamlet development which involve small centers of service facilities surrounded by residential development contained within an open space buffer. These methods are among a number of techniques designed to preserve rural character while considering the natural resources of the land.

3. Determine which techniques would be best suited for Cranston, RI.

Cranston, Rhode Island is unique because both extensive urban and rural areas exist within its boundaries. The older, eastem section of the City is urban and contains many examples of conflicting land uses and disregard for natural resources. The westem section, which is primarily rural and undeveloped, is separated from the eastern section by Interstate 295 . Many city residents and officials have expressed concern over the way development in the westem section of Cranston is evolving. This is a concern that will be addressed by the comprehensive plan, now in draft form. Preliminary data from an analysis performed by the Comprehensive Plan consultant, IEP Inc. of Northborough, Massachusetts has determined that if the western section were to develop with current zoning densities, approximately 3,000 homes could be constructed. If development were 
to continue in the manner found in the northwestem section as a result of access to infrastructural services, the buildout could reach over 8,000 new homes. Such an influx of homes could pose serious problems for the City and its residents in terms of traffic congestion, water supply, solid and liquid waste management, fire and police protection, and provision of other municipal services.

\section{Expected Outcomes}

As populations grow and shift throughout cities and towns, demands are placed on municipalities for housing and services. In some instances the existing housing stock and service facilities are adequate to satisfy the needs of the population. Other times undeveloped, undisturbed land is utilized to satisfy the demand. When the latter occurs, measures should be in place to insure the orderly development of nural areas that have unique natural, and environmental features. This will ensure that the land and the residents, both present and future, are protected from environmental, traffic and safety problems, and that the existing rural atmosphere is preserved to the greatest extent possible.

This research is significant because it will compile growth management tools and techniques that will help growing communities develop in an orderly manner by exposing them to the collective knowledge that exits within the fields of planning and land use. With the help of this information municipalities can institute measures that utilize these methods to meet the specific nural preservation and service provision goals of their communities. 
The remainder of this report included the following components. Chapter Two will discuss the causes and implications of suburban sprawl. Chapter Three will consist of a listing of growth management techniques which can be utilized by growing communities to preserve rural character. Chapter Four discusses the application of each technique to the City of Cranston, RI. Finally, Chapter Five discusses methods of educating the public about new ideas and discusses the probability of implementation for the City of Cranston, RI.

\section{REFERENCES}

1.Flynn, Kevin M. Interview 2/12/92

2.Filipovich, Anthony. Introduction to the City. Kendall/Hunt, Dubuque, Iowa, 1989. 


\section{CHA P T E R T W O}

\section{Ramifications of Suburban Sprawl on Rural Areas}

\section{Introduction}

The development of land, (and those factors that motivate it), impact demographic, social and environmental elements of rural areas. Suburban sprawl is a pattem of development which exists in urban and exurban areas, often along existing, inadequate transportation routes. It is unplanned and most often transforms rural settings from areas that were primarily characterized by agriculture, open areas and sparse populations to areas with multiple uses and higher densities. This chapter discusses the social, economic, demographic and physical catalysts of sprawl and their impacts.

\section{$\underline{\text { Social Factors }}$}

Many of those who once occupied the inner city and called it their home, primarily middle to upper class families, now find the central city unappealing and therefore choose to live outside it. The inner city has increasingly become the home of unassimilated minorities. Population shifts toward the edges of the city have been followed by the suburbanization of business and industry so that "the critical mass of American society is now external to the central city." 


\section{Economic Factors}

Land costs and taxes are economic aspects that also influence migration to suburban and rural areas. Land in urban areas is predominantly more valuable because of availability of services and exposure to amenities associated with business and commerce that exists in the urban environment. Taxes in urban areas are usually higher for the same reasons. The relative economic advantage of living in outer areas can be substantial, therefore, many take advantage of the benefits that these regions have to offer.

\section{Demographic Factors}

Constant increases in urban populations, and the nation as a whole have also increased the demand for suburban and rural land. As populations increase, the demand for housing increases while the amount of space available for it decreases. Since most urban areas have little available space, their confines expand into the outer areas, thus transforming them.

Race and income are other factors which influence the pattern of development. In the past twenty years more low income, minority individuals have located in urban areas while high to middle class white individuals have moved outside the city limits. The appeal of the clean and open suburban and rural areas attract those who can afford to move to those areas. 


\section{Physical Factors}

Infrastructure plays a significant role in the development of land and trends towards outer regions. Infrastructure not only refers to transportation and utility systems it also includes schools, libraries, fire and police personnel, and other public services. Of these listed, sewers, water, and transportation have the greatest impact on development. Upgrades and extension of infrastructure such as transportation and utilities creates a demand for and facilitates development. The development of efficient transportation systems have contributed to the changing American landscapes. With the completion of the majority of the Interstate System, the open country has been transformed into "corridor cities". In other words, development frequently occurs along and around transportation routes, primarily because of the access they provide to other areas. The movement beyond the traditional suburban to exurban (rural) areas has resulted in residential sites that are further from the central city and where population densities are relatively lower. ${ }^{2}$

The introduction or expansion of municipal sewer or water service, or modes of transportation can increase demand for the land where these elements are located. Higher capacity roads or the introduction of a another major mode such as rapid transit increases access into areas allowing more people and goods to be transported in and out of them. The installation of municipal water or sewer services creates a new demand because more and higher density of uses can occur then previously allowed. This is due to an increased ability to dispose of high volumes of waste and supply high volumes of water without the two activities impacting the quality of each other. Because of these circumstances the 
impacts of proposed projects resulting in any of the above activities should be carefully analyzed before they are allowed to go forward.

In rural areas, municipalities must often provide service facilities in order to meet the specific needs of the residents who live there. The introduction of service facilities in rural areas, and the infrastructure required to support them, not only leads to increased pressure for high density development of the land, but also increases traffic and pollution within the area. ${ }^{3}$ This situation can cause serious problems in rural areas which are not set up administratively or financially to deal with these impacts

\section{Impacts of Sprawl}

Suburban sprawl and infrastructure expansion can have many impacts, both positive and negative, on the areas that are affected by them. Fiscal, social, physical, and environmental impacts will be briefly discussed where they apply for the governmental structure and residents of communities that experience sprawl.

\section{Fiscal Impacts}

The fiscal effect of sprawl on government is multifaceted. Negatively, there is the potential need for more municipal services, which can overburden the service delivery system. An elevated demand for garbage pickup, fire and police protection, schools, and other services could cost the community more than it is able to provide with current fiscal resources. While the influx of new families also means a positive increase in taxes, the amount generated by taxes usually constitutes only a proportional amount of the cost of 
providing increased services. In this situation, the only way for a municipality to guarantee the continuation and/or quality of the service delivery is an increase in taxes.

There are also a few major fiscal impacts on residents. As previously mentioned a tax increase could result if new services cannot be financed in other ways. Another aspect is that the residential land in the areas consumed by sprawl becomes increasingly valuable, and those residents who own it reap the financial benefits (and the tax burden). While this may be beneficial to many residents, it may not for others. Younger families may not be able to afford a home of their own due to the high costs of land and housing. Also, this may fall especially hard in agricultural areas, where the price of land for farming may become prohibitive because of its value for development ${ }^{4}$, or an increase in land values may force the development because the agricultural use of the property pay the taxes.

Inversely, central city landowners may experience financial distress if there is a substantial migration towards the community's outskirts. This is due to a decrease in return on property in terms of rent or sales. Also, those residents who are located within the scope of sprawl benefit from the increased services that may not have been available previously, which could reduce personal expenditures on them.

\section{Social Impacts}

Social impacts can also effect both government and citizen. Negative social impacts of sprawl include increased crime, increased traffic congestion, and a lack of social cohesiveness or sense of community. The government answers these problems by 
increased expenditures for public and traffic safety. If unmet, the number of personal losses, injuries, and deaths may increase.

Social tensions may also increase between the older and newer residents of rural areas. The newcomers may have different social, cultural, or educational backgrounds from those of the existing population. They may have more money and different tastes. The older residents may feel as though their lives and homes are being invaded by the outsiders thus becoming resistant to them because and the changes they represent.

\section{Physical Impacts}

The physical impact does not directly affect the people or government, it changes the land and its aesthetics. The areas that become developed are formerly rural with simplistic roads, large tracts of open space, and little commercial uses. Depending on the pattern and density these areas are transformed into high density, multi-use, tracts of land served by many municipal services.

Newly developed areas may be served by either municipal water or sewer services and high capacity roads. With these in place, there is no physical barrier to high density residential development, or commercial or industrial development. The added demand that is a direct result of increased development can extensively alter the demand for water sewage treatment provided by a city or town. For example, the average person uses approximately 75 gallons per day ${ }^{5}$ and if applied to the average household size of 2.5 persons, it can be expected that roughly 187.5 gallons of water per day would be necessary for each new household. This does not take into account a commercial or 
industrial uses proportionally demand for larger amounts of water (depending on the type of use).

Other physical changes that can occur are modifications of modes of transportation, the most prevalent being automobile transportation, and loss of rural character. When sprawl occurs in an area, those transportation routes within the area often must be upgraded to handle the larger capacities and increased level-of-service. Widening of roads, computerization and signalization are the most common improvements. If improvements do not occur, the safety of those who travel on them is compromised.

Finally, "character" is one of the factors which originally attracts individuals to rural areas. As more people move there, it becomes more similar to the urban environment from which people have attempted to escape. A comprehensive development plan for rural areas can prohibit this situation and protect the resources and aesthetics which make them so valuable.

\section{Environmental Impacts}

The quality of the environment has recently become of paramount importance to individuals. Preservation of air and water quality have become two of the most important environmental concerns. When undeveloped areas are populated, air and water quality is often reduced because of the increase in automobile traffic, stormwater runoff, and poorly functioning septic systems (and due to some commercial and industrial activities that are not properly regulated or evaluated). Air quality declines because of increased 
fumes, and water quality drops because of acid rain and toxic runoff which may eventually find its way into aquifers. Water quality can also be degraded if proper practices are not followed in the on-site treatment of sewage. If areas are dependent on wells for water and individual sewage disposal systems (ISDS) for sewage treatment, improper installation, operation, and inspection of ISDS can result in groundwater contamination.

Other concerns involve vegetation, surface water, and wetlands. Destruction of vegetation can destroy vital plant like and disturb or destroy wildlife habitat. Surface water quality may also be reduced when stormwater runoff finds its way into streams and rivers (if it is not properly captured in retention or detention systems). Also, wetlands, which are paramount for flood protection, groundwater purification, groundwater recharge, and habitat, are often filled or destroyed in the midst of development, thus reducing the number of sites capable of these functions.

\section{Conclusion}

As the country's population increases and peoples's interests change, there will always be a necessity for undeveloped land. Complete preservation of such areas is not a feasible goal, but responsible, planned development which fuses development and preservation is. The mistakes of development are visible in most cities and towns in the country, mistakes which have resulted in physical, social, environmental, and aesthetic disasters. The tools to prevent such errors are available for municipalities to utilize. Although they are available, it is well known that planning does not occur in a vacuum 
and that there are usually financial, political, social, or other constraints that may lie in the path of implementation of such techniques. Unfortunately, many rural communities that need these techniques the most are least likely to use them due to a lack of trained municipal staff.

\section{REFERENCES}

1.Patel, Dinker I. Exurbs: Urban Residential Development in the Countryside. University Press of America, Washington D.C., 1980

2.Hughes, James W. The Anals of the American Academy of Political and Social Science: Dilemmas of Suburbanization and Growth Controls. Number 422, November, 1975, pg.63.

3.Sutro, Suzanne. Reinventing the Village. American Planning Association Planning Advisory Service, Report Number 430, December, 1990.

4.Stokes, Samuel N. and Watson, Elizabeth A. Saving America's Countryside, A Guide to Rural Preservation. John's Hopkins University Press, Baltimore, 1989

5.Kupa, John J. Seminar in Ecological Planning, University of Rhode Island, Spring, 1992. 


\section{CHA P T E R THREE}

\section{Rural Preservation Techniques for Communities}

\section{Introduction}

The preservation of rural landscapes has become more important as agricultural land and open space succumb to development. Complete protection from development of all existing undeveloped land within cities and towns is not a probable outcome. Despite this, land use techniques that incorporate rural character and development are available as means to preserve as much land as possible.

Maintaining open space, vegetation, and other natural features not only preserve aesthetics and historic character, but also reduces flooding and erosion, guarantee groundwater recharge, maintain air quality, and sustain wildlife. If less ground cover is removed and not covered by impenetrable surfaces; runoff is reduced because more water is allowed to filter through the soil; less soil is loosened so less erodes; more water reaches aquifers thus recharging them; and air quality is primarily higher because of a larger number of photosynthetic reactions. Also, when rural land is disturbed and urbanized, the wildlife that formerly resided there is driven out of its natural habitat. Development that assimilates the natural features of the site allows wildlife to remain throughout the area while at the same time housing and other facilities needs are met.

This chapter consists of an alphabetical listing of techniques which can be utilized by communities to preserve rural character. Each listing consists of the following elements: description; goals; methods of adoption; methods of implementation; advantages; limitations; complementary tools; and sources of the information. 
Description:

Agricultural Preservation Districts can be established as overlay zones to preserve prime farmlands, and to minimize adverse development impacts and conflicts. Farmlands are permanently preserved by deed restriction. This technique is predominantly used to preserve large tracts of land over 100 acres in size.

Goals:

- To promote the practice of farming and minimize conflicts with other uses

- To protect prime agricultural lands for future flood protection

- To preserve historic, scenic, open space, and other farm-related values which will help to define the community's character

- To preserve the most important farmlands for future agricultural use

\section{Adoption:}

Agricultural Preservation Districts are amendments to the zoning ordinance which must be adopted by the appropriate administrative governmental body or board.

Implementation:

Once the amendment is passed and district boundaries are included in the zoning map, the regular zoning practices and permitting processes apply for the area in question.

Advantages:

- Lands most productive and suitable for farming can be exclusively reserved for that use only

- Historic, scenic, open space and other farm-related values remain intact

Limitations:

- An overabundance of agricultural land may restrict needed for other uses such as residential, commercial and industrial

- Reduces tax revenues because agricultural uses are often taxes at lower rates

Complementary Tools:

- Purchase of Development Rights

- Transfer of Development Rights

- Overlay Districts

- Land Trusts

Sources:

- References 1,2,3,15 


\section{Chnstier Developpment}

\section{Description:}

Cluster development reduces zoning requirements for minimum lot size, frontage, and building setbacks. Land gained by the reductions are preserved as open space. The maximum number of units in a cluster may be the same number allowed in a standard subdivision or include additional units called density bonuses. Density bonuses may be given for the inclusion of preferred features such as the preservation of significant additional open space, and extension of water or sewer lines, or the inclusion of affordable housing units. Bonuses must be clearly defined in zoning regulations. Cluster development is offered as an altemative development technique and is not specifically outlined as district(s) within the official map. A minimum acreage is frequently required for cluster development.

Goals:

- To preserve open space and other natural features

- To provide an altemative to standard subdivisions

- To reduce costs of roads and utilities construction

Adoption:

- Adopted as an amendment to the zoning ordinance and is subject to those procedures

\section{Implementation:}

Since the cluster zone is usually a development option, it is up developer whether or not the development will be of cluster design. Unless the development is a public project, the municipality usually cannot dictate where cluster development will occur.

\section{Advantages:}

- Provides an incentive (lower development costs) for private investment

- Preserves open space at a low cost to the municipality

- Reduces impermeable surface area (less roadways)

- Provides an alternative development pattern

- Encourages more flexible site design

- Reduced maintenance costs

Limitations:

- The required open space may not be properly maintained or available to the general public

- Poor public perception/understanding of clustering as being too uban

- Requires sophisticated local staffing to properly implement

- Loss of tax revenues from the open space areas 
Complementary Tools:

- Planned unit development

- Site plan review

Sources:

- References $1,2,3,4,15$

Figure 3.1 - Conventional versus Cluster Development Conventional development of a former farm

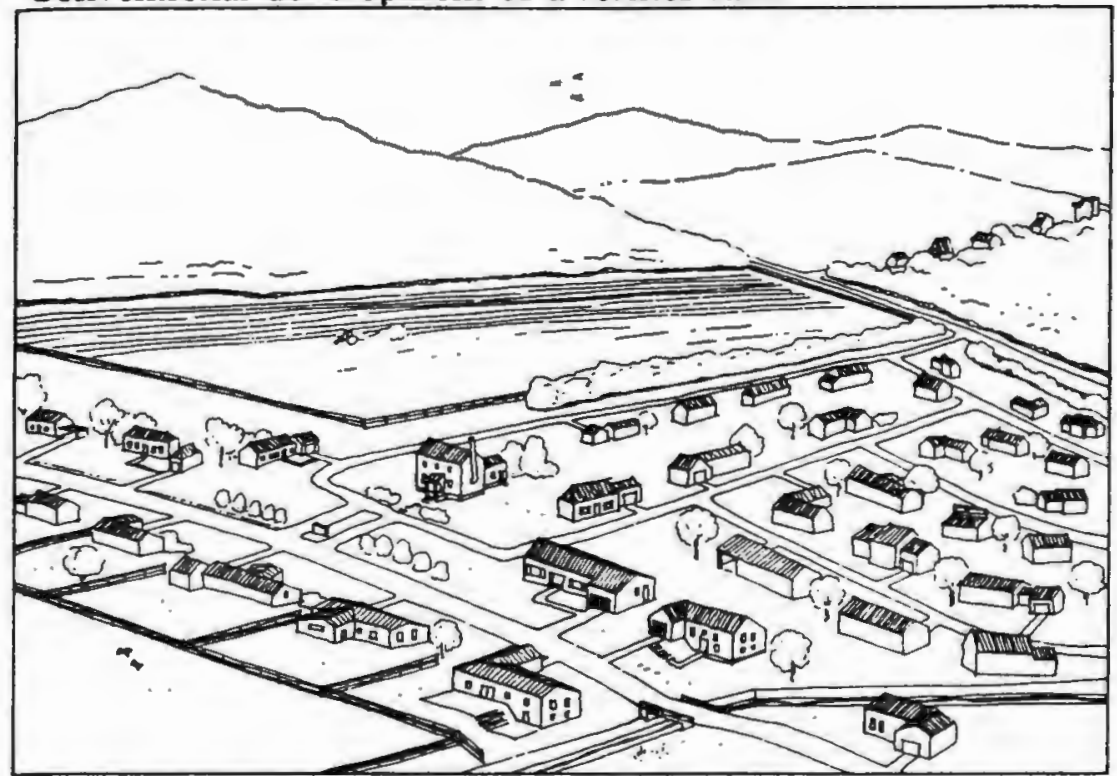

Cluster development of the same land

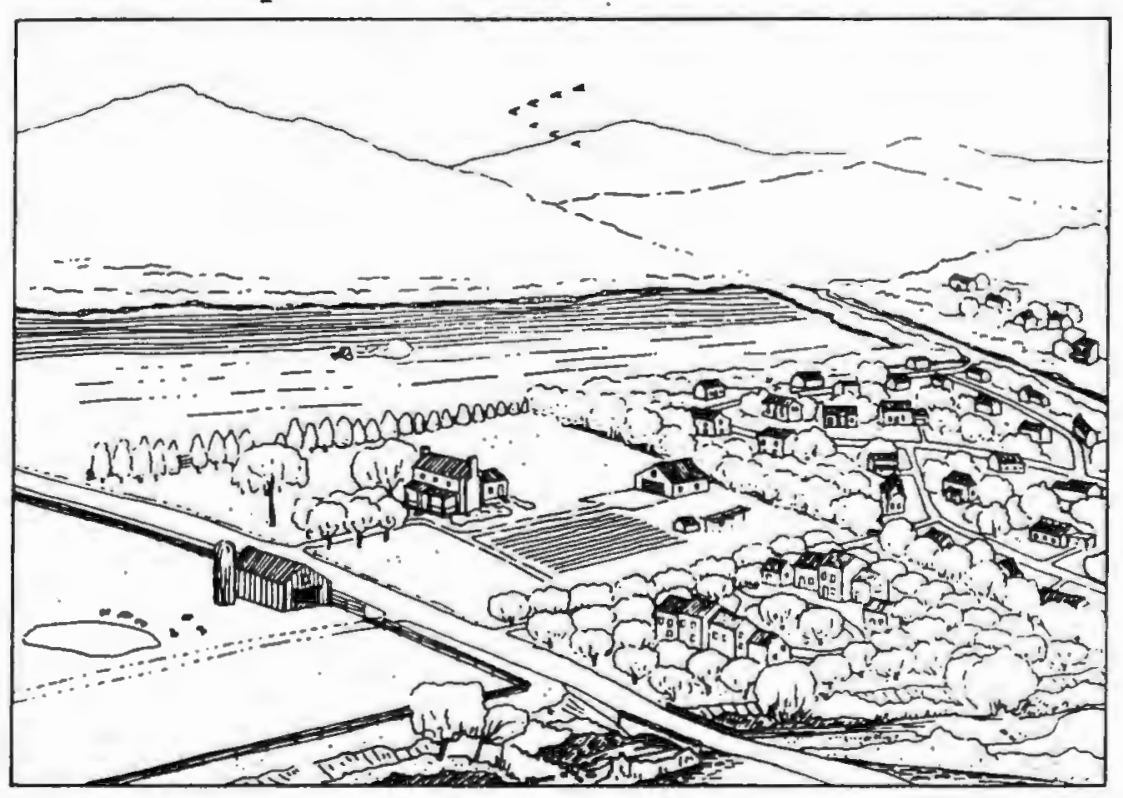

Source: Stokes and Watson (1989) 


\section{Compromelhensive (Mastar) IPlam}

\section{Description:}

A municipal document which provides an inventory of resources and a framework for the physical development of a community. It is usually broken down into components including land use, infrastructure, housing, recreation, economic development and other functional areas. For each functional area strategies are proposed to guide their development. Comprehensive plans are usually updated once every ten years, a process which lasts approximately one to two years.

Goals:

- Provision of necessary infrastructure to support development

- Protect and promote health, safety, and welfare

- Management of residential and commercial growth

- Protection of natural resources and open space

- Direction of other community aspects

- Allocate areas for various land uses

Adoption:

The comprehensive plan must be adopted by the appropriate municipal governing body and/or planning commission or board.

\section{Implementation:}

The general intentions of the plan must be specifically carried out in a revised zoning ordinance, subdivision regulations and site plan review. Public input is required at all stages of plan development.

\section{Advantages:}

- Development of functional areas are specifically outlined

- Provides guidance for extended period of time

Limitations:

- Ineffective if its intentions are not carried out in zoning ordinance and other regulations

- Ineffective if not updated regularly to meet the changing needs of the community

- Does not necessarily consider non-physical planning problems

- Difficult to form a consensus to establish ideal land use patterns 
Complementary Tools:

- Zoning Ordinance

- Subdivision regulations

- Capital improvement budget

- All land use/growth management techniques/tools

Sources:

- References $1,2,3,14,15,16$ 


\section{IFer Simple Iamd Acegruisitition}

Description:

Fee simple land acquisition is the necessary full title purchase of property a community needs to achieve specific goals. Communities use this method for purchasing land for recreation, conservation, aquifer and watershed protection, historic site preservation, affordable housing and other community needs.

Goals:

- Acquire land to satisfy community needs and protect community resources

Adoption:

Purchase of development rights programs must be instituted by a municipality, therefore, it must become town policy. Adoption is contingent on approval of the governing body, board, or commission responsible for such actions.

Implementation:

Areas of critical environmental concern and community resources that are deemed necessary to acquire are considered for acquisition and obtained if appropriate.

Advantages:

- Effectively protects land and critical resources or promotes desirable development

- Compensates landowner

Limitations:

- Appropriation of funding may be too slow to purchase desired land

- Feasible only on a limited scale

- Very expensive

Complementary Tools:

- Land Banking

- Real estate transfer tax

Sources:

- References 1,2,3,16,17 
Lramad Bromanginge

Description:

Land banking is the public acquisition of lands, primarily for open space, that is financed through a land trust funded by real estate transfer taxes. Land purchased can also be developed either by public or private organizations, once any land is placed back on the market. This allows a community to influence the location and rate of growth by selecting the parcels to be sold.

Goals:

- Preserve open space through land acquisition, park rehabilitation, agricultural or conservation restrictions, and other mechanisms

- Establish a local fund to support the development of affordable housing

- Establish a local fund for an open space preservation program

- Influence the location and rate of growth

Adoption:

Enabling legislation is required for this practice which can take place at state and community levels. Approval must come from the governing municipal body, commission, or board. A real estate transfer taxing system must also be in place in order for land banking to be successful.

Implementation:

Land bank commissions are set up to determine what areas, and tracts of land should be acquired to meet the goals of the state or community. These sections are then studied, assessed and the acquisition process is initiated if the land meets all criteria.

\section{Advantages:}

- Effectively acquires open space and other valuable land at a low cost to the public

- All property owners forced to bear some of the costs of growth management

- Reduces financial burden on individual property owners

- Effectively determines the location of growth

\section{Limitations:}

- Difficult to determine what areas should be purchased, preserved, or developed

- Potential disruption of land markets 
Complementary Tools:

- Real estate transfer tax

Sources:

- References 1,2,3,4,18 


\section{Description:}

Land trusts are private organizations that provide funding to acquire land and development rights in order to protect open space. The trust competes in the land market with other purchasers. The only economic advantage a land trust may have in the market is that any difference between the sale price and fair market value may be taken as a tax deduction. The trust must meet certain criteria to obtain this tax deduction, however, there are persons who would prefer to donate their land, rather than see it developed at any point in the future.

\section{Goals:}

- Preserve areas of significant natural diversity, important recreational opportunities, and historic preservation of farmland and open space.

\section{Adoption:}

Land trusts are private organizations so no govemmental adoption procedures are required. They must, however, conform to specific guidelines in order to be considered non-profit organizations.

\section{Implementation:}

Land that trusts see fit for preservation are purchased, or are lobbied for donation, if possible, by the trusts or by other private preservation-minded individuals or corporations.

\section{Advantages:}

- Act more quickly and discretely than a public entity

- Offer an alternative to govermment ownership

\section{Limitations:}

- Possible increase in overall land prices and housing costs in other properties

- Decrease in tax base due to tax deductions

- Requires extensive funding sources

Complementary Tools:

- Fee simple land acquisition

Sources:
- References $1,2,3,4$ 


\section{Description:}

Overlay districts superimpose restrictions or development options on areas in zoning districts. They are usually used when there is a special public interest in an area that does not coincide with already mapped traditional zones. Overlay districts do not affect the density or use regulations present under existing zoning, rather, it creates an additional set of requirements to be met when the special resources protected by the district would be affected by a proposed change. They may cover parts of several districts (zones) or only a portion of an underlying zone.

Goals:

- Preserve and protect specific community environmental, natural, historic, and scenic resources

- Encourage specific development patterns

Adoption:

Overlay Districts are amendments to the zoning ordinance which must be adopted by the appropriate administrative governmental body or board.

\section{Implementation:}

Specific overlay districts should be written separately from others because they are protecting different features. Each district should be a distinct amendment to the zoning ordinance and should be outlined on the official map. Any activities that take place following adoption should conform to the overlay district in addition to original zoning requirements.

\section{Advantages:}

- Easier to implement than a zoning change

- Overlap many zones if necessary

- Targets specific planning concerns

\section{Limitations:}

- May be relatively expensive to implement if the district requires special activities/safeguards

\section{Complementary Tools:}

- Performance Standards

- Special Permits

Sources:

- References $1,2,3,4,10,11,19$ 


\section{IPerpformanme Zominge}

Description:

Performance zoning determines the permissible effects of a development rather that listing the types of uses permitted. Development is based on the carrying capacity of the land. municipal infrastructure, and services to support growth. This type of regulation places the burden of demonstrating that the zoning criteria are met on the developer. This method is point based assessment of developing land.

Goals:

- Ensure that development does not overburden infrastructure and service facilities

- Provide detailed analysis of development

\section{Adoption:}

Performance zoning is set up similarly to conventional zoning ordinances. The same procedures for drafting and adoption hold true.

\section{Implementation:}

The same procedures apply as in conventional zoning. Development must conform to the allowed uses in an area, and building permits are not issued unless the development meets such standards. The difference is the methods of determining is the proposed development is acceptable in an area.

\section{Advantages:}

- Relates intensity of growth to municipal and environmental capacity to support growth

- Guides growth to most appropriate locations

- Outlines desirable qualities of growth

Limitations:

- Requires substantial and sophisticated analysis for proper implementation and enforcement

Complementary Tools:

- Special permits

- Site plan review

Sources:

- References $1,2,3,4,9$ 


\section{IPlammed Unim Developpmemt (IPUD)}

Description:

Planned unit developments stipulate that subdivision and zoning regulations apply to the whole project rather than its individual lots. Densities are calculated on a project-wide basis, and residential, commercial, and industrial uses are allowed as are a variety of building types and requirements for open space. PUD's are similar in to cluster development and include a requirement of minimum acreage for development.

Goals:

- To permit diversity and allow comprehensive rather than piecemeal development of an area as a whole

- To provide alternative development patterns.

\section{Adoption:}

- Adopted as an amendment to the zoning ordinance and is subject to those procedures and approval by the municipal governing body, board, or commission

Implementation:

Since planned unit development is a development option, it is up to the developer as to whether or not the development will be a PUD. Unless the development is a public project, the municipality usually cannot dictate where PUD occurs unless a planned unit development zone is set up.

\section{Advantages:}

- Promotes comprehensive site development and linkages between areas

- Provides opportunity for innovative mixed-use development

- Allows for more flexible land-use regulations

- May preserve open space at a low cost

Limitations:

- Sometimes perceived by local officials as a way of bringing an urban environment into a suburban setting

- If designed poorly problems can arise in the coexistence of residential, commercial, and industrial areas

- Poor public perception/understanding of PUD as being too urban

- Requires sophisticated local staffing to properly implement 
Complementary Tools:

- Performance standards

- Subdivision regulations

- Site plan review

- Special permits

Sources:

- References 1,2,3,4,7 


\section{Description:}

The purchase of development rights involves acquisition of the development rights for a parcel by a state or municipality in retum for monetary compensation for the landowner. In other words, PDR enables the unused development potential, and other rights, of a parcel to be sold, and those rights are no longer attached to that parcel. The outcome is that the land is bound by a conservation easement which runs with the land either in perpetuity or for a period of time specified in the deed. This program is primarily used by state and county-wide governments because of the high costs that can be incurred in acquisition of development rights. Despite this, some communities utilize it also.

Purchase of development rights programs were primarily set up to protect agricultural land and open space while compensating the farmer/owner for the community goal of preservation of community character. Development of any kind is prohibited, (except for the farmer, his children, or farm labor), nor is any public access allowed. At the same time the land remains in agriculture, thus preserving this vital production function.

Goals:

- Preserve open space and agricultural land

Adoption:

Purchase of development rights programs must be instituted by a municipality, therefore, it must become town policy. Adoption is contingent on approval of the governing body, board, or commission responsible for such actions.

Implementation:

If valuable agricultural land or open space is in jeopardy of being lost to development, a community may deem it necessary to exercise this tool to protect it.

\section{Advantages:}

- Potential for permanent preservation of agricultural land, open space, or other valued community land

- Landowner is compensated for the loss in value of the land

\section{Limitations:}

- Acquisition costs are expensive to the community, and if too expensive, the program is ineffective

- Undevelopable land becomes less valuable and reduces the tax base

- Feasible only on a limited scale 
Complementary Tools:

- Overlay districts

Sources:

- References $1,2,3,4,5,16$ 


\section{Specianl (Use) Peramints}

\section{Description:}

Special permits regulate activities that may create safety problems or affect neighboring land uses or the community as a whole because of their size or special character. In granting a special permit, conditions may be imposed by the municipality that relate to on and off-site physical improvements, limit the hours of use, and other conditions which the town believes are justified due to the impacts of the project. Public input must be accepted before a special use permit is granted.

Goals:

- To protect the community from activities that may endanger it and its residents

Adoption:

Those activities requiring special use permits must be specifically listed in the zoning ordinance within each zone or district. Each activity is an amendment to the ordinance and must go through proper amendment procedures.

\section{Implementation:}

If a perspective use is an activity that requires a special use permit, the builder must apply for such a permit before a building permit can be issued. Some ordinances may stipulate the conditions that must be met before a permit can be issued others are subject to conditions set by the appropriate board or commission which may be situational.

\section{Advantages:}

- May be used to provide financial relief in rapidly growing communities which are forced to expand infrastructure

- Requires an appropriate design for each site

- Mitigates on and off-site development impacts

\section{Limitations:}

- Considers the impact of individual projects, not the overall effect of total development

- Problematic activities may not require a special use permit if they have not previously occurred

- Adds to the complexity of the development process 
Complementary Tools:

- Site plan review

- Cluster development

- Planned unit development

- Impact fees

Sources:

- References $1,2,3,4,16$ 


\section{Sitioe IPlam $\mathbb{R}$ evilew}

\section{Description:}

Site plan review is an administrative procedure that is used to ensure compliance with design requirements for drainage, access, building size and location, landscaping, and parking. Detailed conditions are stipulated which development must conform to. In some areas discretion can be left the review party/boards which increases the power of negotiation. Thresholds are stipulated which determine when and for what types of land use require site plan review.

Goals:

- To ensure that the design and layout of development will constitute suitable development and will not result in detriment to the community, neighborhood, or environment

- To assure adequate review of plans for developments which may have significant impacts on traffic, drainage, municipal and public services, environmental quality, and community character

\section{Adoption:}

Site plan review should be an element of the subdivision and other land development regulations, and is adopted with them.

\section{Implementation:}

All subdivisions of land of two or more lots, and other buildings that fall under other density or use requirements must be subjected to site plan review before a building permit is issued.

\section{Advantages:}

- Permits a community to balance its needs and limitations within certain constraints

- Prevents unattractive, careless, or haphazard development

- Improves administration

- Assures compliance

\section{Limitations:}

- Constrains a review board's ability to negotiate because of the limited scope of review

- Involves detailed review of projects with sometimes limited resources

- Requires sophisticated professional staffing to properly implement 
Complementary Tools:

- Special permits

- Cluster zoning

- Planned unit development

Sources:

- References 1,2,3,4,5,14,16 


\section{Description:}

This neotraditional district is a type of overly district and is an alternative to conventional mixed-use planned unit development. In essence, the TND reflects the traditional American town. The ordinance proposes to establish the bonds of an authentic community through pedestrian orientation and the provision of public spaces. TND combines elements of PUD and village development and usually ranges from 40 to 200 acres.

Goals:

- Reduce the influence of the automobile on suburban design

- Re-emergence of a sense of community within environs

- Preservation of open space

- Provision of public spaces

\section{Adoption:}

Traditional neighborhood districts adopted as an amendment to the zoning ordinance and are subject to those procedures and adoption by the municipal governing body, board, or commission.

\section{Implementation:}

TND's must be outlined in the official map of the municipality. Once areas are designated for this development, the project can go forward. Development should be phased, well planned and designed. Due to the large size of the project, multiparty coordination and funding may be necessary.

\section{Advantages:}

- Services and infrastructure are concentrated in and directed to specific areas

- Growth is concentrated in and directed to specific areas

- Coordination between all functional areas

- All uses are within walking distance

- Virtually self-sustaining

- Open space is preserved

\section{Limitations:}

- Infrastructure required to sustain village may lead to high density development in nearby areas if the correct controls are not in place

- Economic consequences are varied for various landowners

- Large tracts of land are required

- May be difficult to implement 
Complementary Tools:

- Overlay districts

- Easements

Sources:

- References 12,20 


\section{Description:}

The transfer of development rights separates the right to develop land from the property rights associated with land ownership. Property owners in "sending zones" transfer their development rights to land parcels in "receiving zones", usually for money. The property in the sending zone is then limited in its future development depending on which rights attached to it have been transferred. In other words, TDR's enable the unused development potential of a parcel of land to be transferred, thus those rights are not longer attached to that parcel. TDR increases the amount of development on a receiving parcel of land and eliminates or reduces the right to develop a sending parcel.

Goals:

- Protect natural, historic, and agricultural resources

- Influence the location of development

Adoption:

The ability to transfer development rights must be recognized by the municipality. This is done by setting up sending and receiving areas or zones, which are amendments to the zoning ordinance.

Implementation:

Any landowner in a sending zone can transfer development rights to a landowner in a receiving zone. There must be, however, a market or demand for such transfers to take place. Also, the receiving zones must be well suited for immediate development, and must increase densities sufficiently so that use of the rights becomes financially attractive for developers.

Advantages:

- Promotes development in desirable locations and conservation in others

- Provides economic relief to property owners affected by land use regulations

- Preserves lands at low cost to the public

Limitations:

- Locating potential "target" sites for receiving development rights is difficult

- Assessing the value of development rights is difficult

Complementary Tools:

- Traditional neighborhood districts

- Village development

- Overlay districts 
Sources:

- References $1,2,3,4,6,16,18$

Figure 3.2 - Transfer of Developmemt Rights
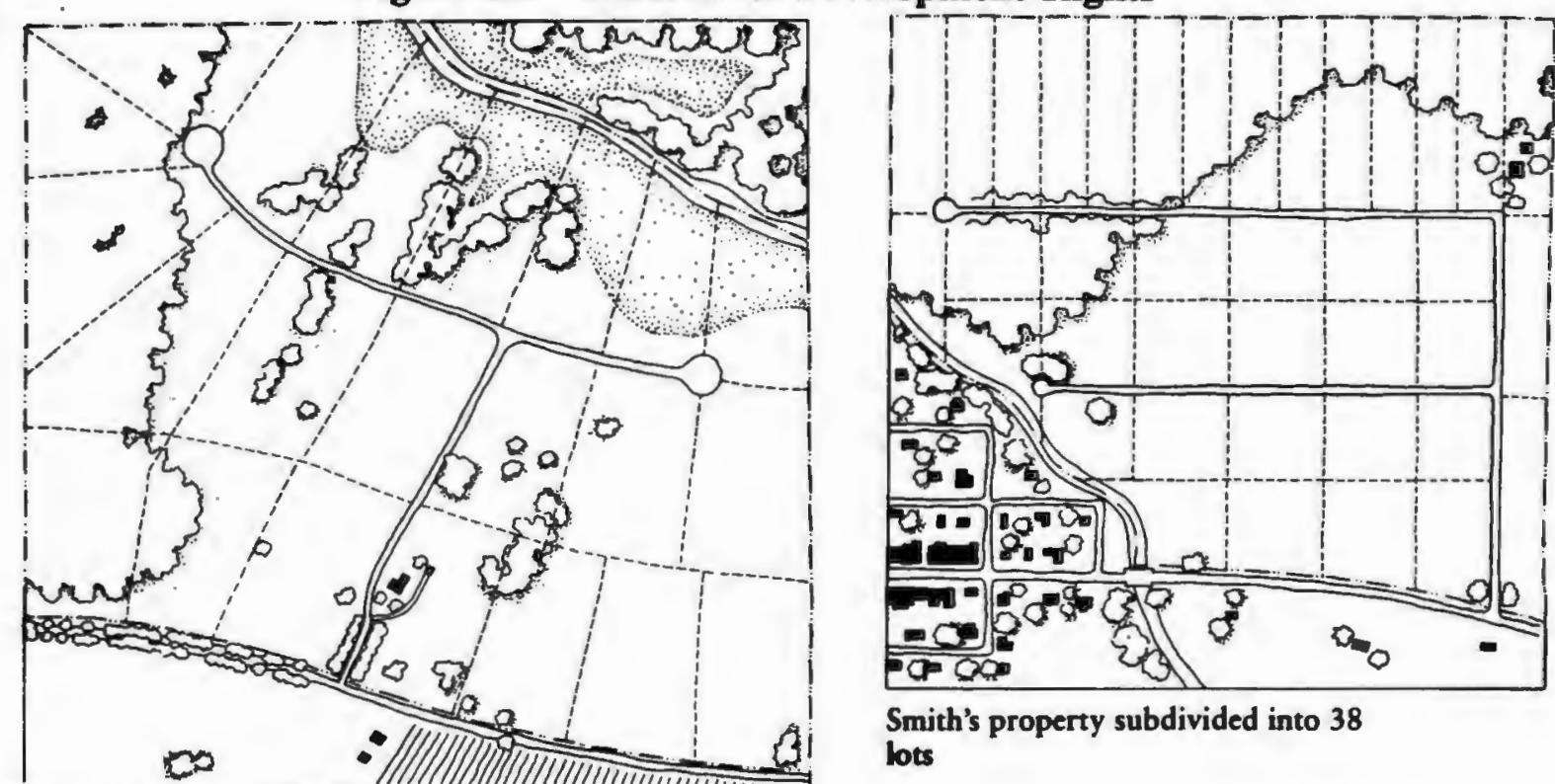

Smith's property subdivided into 38

Brown's farm subdivided into 22 lots

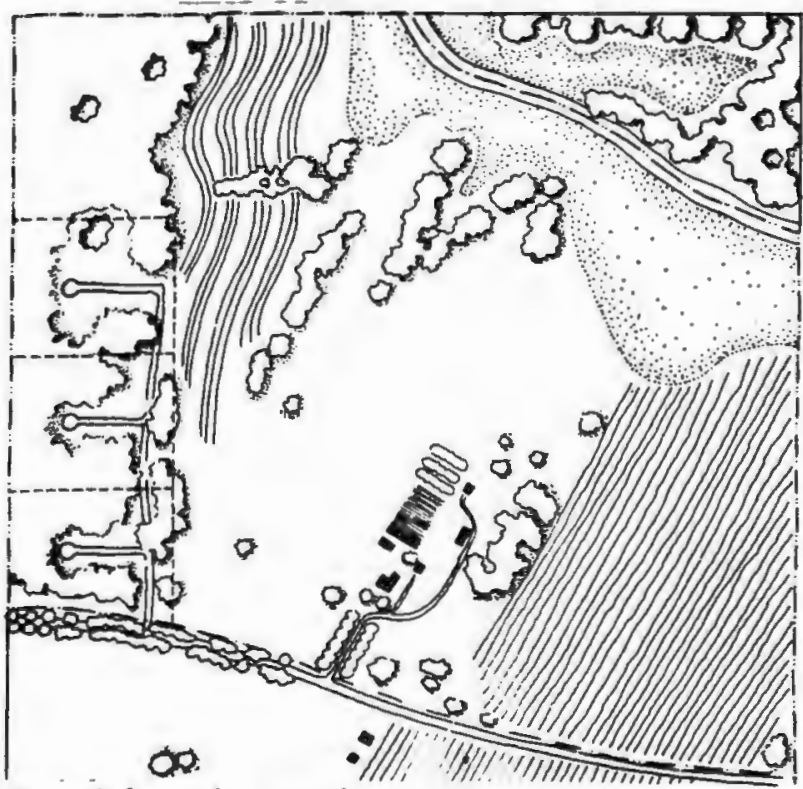

Brown's farm after transferring 18

lote to Smith

Source: Stokes and Watson (1989)

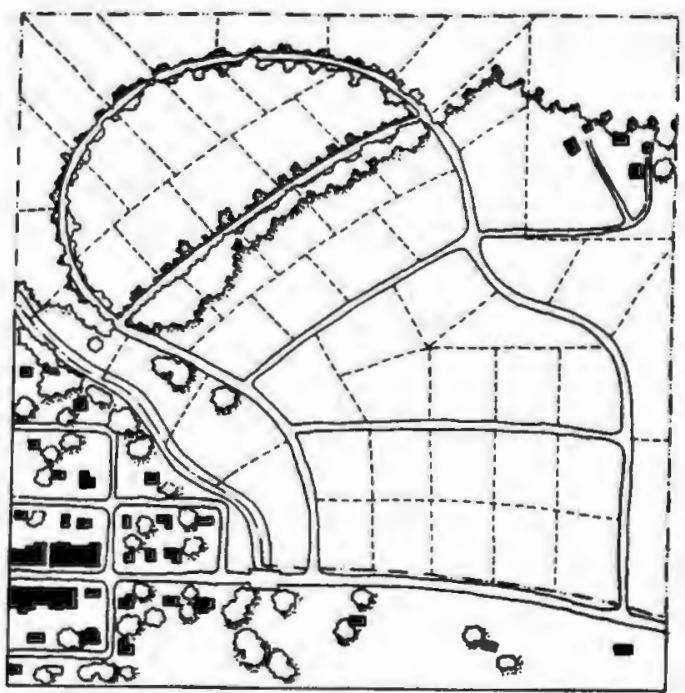

Smith's property has 56 lots after receiving 18 loss from Brown 


\section{Voillange Developprinems}

\section{Description:}

Village development is a neotraditional type of development which goes back to the basics traditional development. A village is a predominantly residential area with supporting commercial and public activities lying near its center. It does not haver a clear distinction between residential and non-residential areas. It is compact relative to its surroundings and to traditional suburban tract development, and it is easily distinguishable for the surrounding undeveloped land. Because no activity is more than a quarter of a mile from any other use, village development seeks to transform development from being primarily automobile oriented to areas that are pedestrian oriented.

Goals:

- Cluster residential and non-residential uses while preserving open space

- Re-orientate development to focus on pedestrian movement

- Increase social and cultural interaction between residents

Adoption:

Village Districts are amendments to the zoning ordinance and are subject to the practices procedures for approval by the governing municipal body, board, or commission.

Implementation:

Since village development is a relatively new type of growth management technique, it is in a stage of infancy. While design and drafting of performance standards for this type of zone is fairly simple, implementation is more difficult because it may involve large tracts of land with numerous owners.

Advantages:

- Services and infrastructure are concentrated in and directed to specific areas

- Growth is concentrated in and directed to specific areas

- Virtually self-sustaining

- Open space is preserved

- Pedestrian oriented

- Neighborhood unity

Limitations:

- Infrastructure required to sustain village may lead to high density development in nearby areas if the correct controls are not in place

- Requires sophisticates professional staffing to properly implement

- Economic consequences are varied for various landowners

- May be difficult to implement 
Complementary Tools:

- Easements

- Overlay districts

- Purchase of development rights

- Transfer of development rights

Sources:

- References 12,13

Figure 3.3 - Village Development

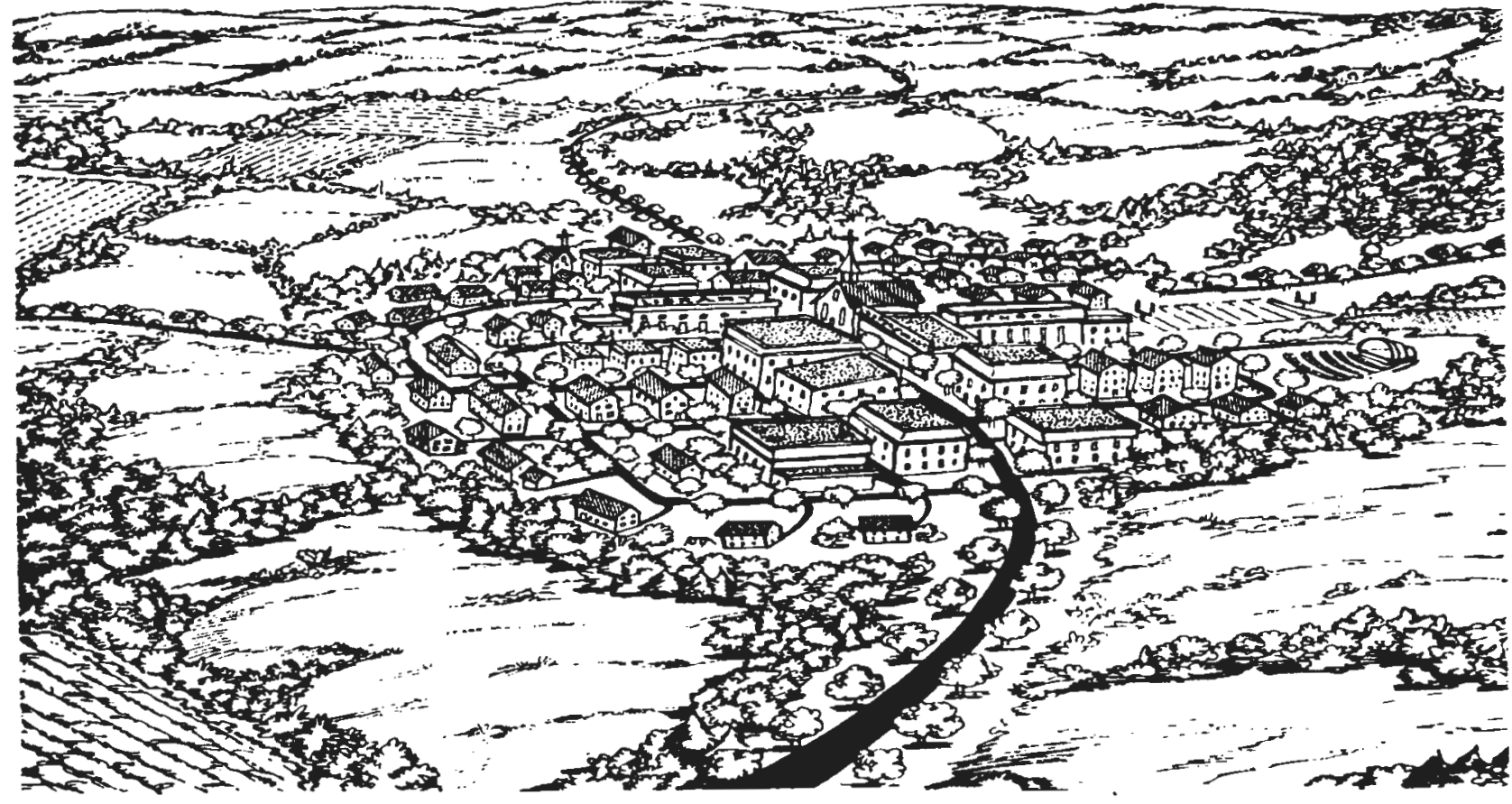

Source: Sutro (1990) 


\section{Conclusion}

The techniques and tools listed in this chapter provide many of the options communities have in attempting to control growth. The entire collection of techniques encountered were not listed because many are outdated, inefficient, or legally weak. Also, for the purpose of this project, the selected techniques reflect those that would be used in communities characterized by some partial exposure to infrastructural components and at least an incorporated ruling entity in place.

Many of the techniques included such as the traditional neighborhood districts, village development, and planned unit development are similar (and many are dissimilar). Application of any method is situational and dependent on factors such as funding, government, complexity, zoning, staff capability, and other factors. Because of this, some that may be implementable in one community may not in others. The next chapter will consist of an analysis whose outcome will produce the best recommended actions for the City of Cranston, Rhode Island based on the controls listed in this chapter. 


\section{REFERENCES}

1. Metropolitan Area Planning Council. The Growth Management Catalogue; A Compendium of Growth Management Techniques. Boston, MA, November 1987.

2. Stokes, Samuel N. and Watson, Elizabeth A.. Saving America's Countryside, A Guide to Rural Conservation. Johns Hopkins University Press, Baltimore, MD, 1989.

3. Pioneer Valley Planning Commission. Land Tools and Techniques For Successful Managing Growth and Development. Springfield, MA, May 1988.

4. Metropolitan Area Planning Council. Growth Management Techniques. Boston MA, April 1978.

5. Daniels, Thomas L. The Purchase of Development Rights, Preserving Agricultural Land and Open Space. Joumal of the American Planning Association, Autumn 1991.

6. Pizor, Peter J. Making TDR Work. Journal of the American Planning Association, Spring 1986.

7. Thomas Planning Services. Growth Management Strategies, Egremont and Lee Massachusetts. Boston, MA, December 1987

8. Central Massachusetts Regional Planning Commission and Metropolitan Area Planning Council. Inventory of Growth Management Techniques. Boston, MA, May 1985.

9. Planning Magazine. You Don't Have to be Big to Like Performance Zoning. American Planning Association, May 1985, pp.16.

10. Rahenkanmp, John E. and Hengst, William G. Road Corridor Overlay Zoning for Roadside Enhancement. Urban Land Magazine, May 1988, pp. 11.

11. Zoning News. Standards for Overlay Districts. American Planning Association, August 1991, pp. 1.

12. Zoning News. New Traditionalism in Suburban Design. American Planning Association, June 1989, pp. 1.

13. Sutro, Suzanne. Reinventing the Village. American Planning Association Planners Advisory Service, Report Number 430, 1990. 
14. Branch, Mellville C. Comprehensive City Planning, Education and Explanation. American Planning Association Planners Press, Chicago, IL, 1985.

15. Cranston City Planning Commission. City of Cranston, Rhode Island Comprehensive Plan. IEP, Inc., Northboro, MA, January 1992. 1978.

16. Metropolitan Area Planning Council. Balanced Growth Manual. Boston, MA,

17. Massachusetts Association of Conservation Commissioners. Environmental Handbook for Massachusetts Conservation Commissioners. Tufts University, Medford, MA, 1985.

18. Brower et al. Managing Development in Small Towns. American Planning Association, Chicago,Il.

19. Metropolitan Area Planning Council. Water Resources Protection Techniques. Boston, MA, 1978.

20. Duany, Andres. Suburban Sprawl or Livable Neighborhoods. Planners Training Service Symposium on Neotraditional Town Planning, Washington, D.C., 1990. 


\section{CHAPTER FOUR}

Applications for the City of Cranston, Rhode Island

\section{$\underline{\text { Introduction }}$}

The City of Cranston has the unique opportunity to change the evolution of land use in its undeveloped areas because of the Rhode Island Comprehensive and Land Use Regulation Act. This Act, passed by the State legislature in 1988, requires all cities and towns in Rhode Island to produce a comprehensive plan, thus allowing the City to alter the development policies that have been in effect since the last comprehensive plan, which was created in 1975 . Since that time, times have changed and so have the goals of the City. Preservation of open space and protection of natural resources, especially in western Cranston, are among some of the City's main concerns. With the help of the new comprehensive plan, and the subsequent amendments to the zoning ordinance, Cranston can choose to install measures which will aid in reaching these aims. In addition to their specific goals each community must also meet the general goals of the Act as specific which include:

1) To promote orderly growth and development that recognizes the natural characteristics of the land, its suitability for use and the availability of existing and proposed public and/or private services and facilities; and

2) To encourage the use of innovative development regulations and techniques that promote the development of land suitable for development while protecting our natural, cultural, historical and recreational resources and achieving a balanced pattern of land uses. ${ }^{1}$

The purpose of this chapter is to review all of the growth management tools and techniques compiled in Chapter Three, and comment on their applicability to the City of 
Cranston as a means to control growth insofar as development and rural preservation complement each other.

\section{Govemment Structure}

Since not all cities are alike, the methodology in preserving rural character will vary. Cranston, the third largest city in Rhode Island, possesses a complex mayor/city council government structure and has many land use controls in place. The planning structure includes a seven member planning commission which is served by a five member planning department. There is also a zoning board of review appointed by the Mayor and the City Council.

Cranston already utilizes some of the techniques catalogued in Chapter Three. They include comprehensive planning, cluster development, overlay districts, planned unit development, and special permits. The existence of these measures affords the municipality more efficiency in implementing an overall vision for the western section and all other undeveloped areas. In addition, it demonstrates the responsiveness of the Planning Department to implement new techniques as a means of regulation in response to land use problems. These methods, in addition to others can be used collectively, or on an individual basis to preserve rural landscape in the midst of suburban sprawl.

Table 4-1 on page 50 lists the growth management techniques compiled in Chapter Three and specifies whether or not they can effect or enhance the quality of development, environmental preservation or development density. The table also states which techniques are recommended to be used in Cranston. 
Table 4-1. Characteristics of Rural Preservation Techniques

\begin{tabular}{||l|c|l|l|c||}
\hline Technique or tool & $\begin{array}{l}\text { Quality of } \\
\text { Development }\end{array}$ & $\begin{array}{l}\text { Environmental } \\
\text { Preservation }\end{array}$ & $\begin{array}{l}\text { Development } \\
\text { Density }\end{array}$ & $\begin{array}{l}\text { Apply in } \\
\text { Cranston }\end{array}$ \\
\hline \hline $\begin{array}{l}\text { Agricultural } \\
\text { Preservation Zoning }\end{array}$ & no & yes & yes & no \\
\hline Cluster Development & yes & yes & yes & yes \\
\hline Comprehensive Plan & yes & yes & yes & yes \\
\hline $\begin{array}{l}\text { Fee Simple Land } \\
\text { Acquisition }\end{array}$ & no & yes & yes & no \\
\hline Land Banking & no & yes & yes & yes \\
\hline Land Trust & no & yes & yes & yes \\
\hline Overlay District & yes & yes & yes & yes \\
\hline Performance Zoning & yes & yes & yes & no \\
\hline $\begin{array}{l}\text { Planned Unit } \\
\text { Development }\end{array}$ & yes & yes & yes & no \\
\hline $\begin{array}{l}\text { Purchase of } \\
\text { Development Rights }\end{array}$ & no & yes & yes & no \\
\hline Special Permits & yes & yes & yes & yes \\
\hline Site Plan Review & yes & yes & yes & yes \\
\hline $\begin{array}{l}\text { Traditional } \\
\text { Neighborhood District }\end{array}$ & yes & yes & yes & no \\
\hline $\begin{array}{l}\text { Transfer of } \\
\text { Development Rights }\end{array}$ & yes & yes & yes & yes \\
\hline Village Development & yes & yes & yes & yes \\
\hline \hline
\end{tabular}




\section{Growth Management Applications}

\section{Agricultural Preservation Zoning}

This method is not recommended because large amounts of land are required to implement it. Agricultural preservation zoning usually earmarks lands of 160 acres or more, and is prevalent in communities with vast amounts of agricultural land that have a great dependency on agriculture. Cranston does not have many farms of that size nor does it depend greatly on agriculture. Other, easier methods of open space preservation could be implemented.

\section{Cluster Development}

To date, two developments have taken advantage of the cluster design option in Cranston, and another two developments are being proposed. Although the occurrence of cluster development is more frequent, the City should require its use more often. Increased use of cluster development would substantially preserve natural, historic, and physical resources, all at little cost to the public. The City could feasibly require that all development in undeveloped areas conform to cluster or other rural preservation designs where appropriate. (The comprehensive plan does promote cluster development in a two acre zone by requiring non-cluster development to maintain a five acre density.)

\section{Comprehensive Plan}

As aforementioned, the last comprehensive plan for the City was written in 1975. Due to State legislation, Cranston is required to do something that should have been done 
in 1985, produce another comprehensive plan. Although it did take 16 years for the comprehensive planning process to begin, it is not due to a lack of initiative on the part of the municipality, rather a lack of funding and manpower, a void that the enabling legislation, and its accompanying funds have filled.

The 1992 Comprehensive Plan outlines new goals for the city which are consistent with the needs and wants of Cranston's residents. This is vital because it gives legal backing to the zoning, subdivision, and site plan review regulations, provided they are brought into conformance with the intentions of the Plan. While the Plan provides the direction, the City's land development regulations, (zoning and subdivision), will be the major vehicles that will implement the plan.

\section{$\underline{\text { Fee Simple Land Acquisition }}$}

Fee simple land acquisition is a very effective way of gaining property as a means to preserve open space. The main flaw of this technique is its high costs. Complete purchase of property is something that rarely occurs, especially in the trying financial times municipalities are experiencing today. Less than fee land acquisition or purchase of development rights is a more feasible approach to open space preservation, especially since more open space can be preserved with less financial resources.

\section{Land Banking}

This method is a good one provided there is a productive real estate transfer tax in place. If so, the cost of acquisition does not fall on the general public, but on buyers 
and sellers of property. The tax is usually a small percentage (two percent on the average) of the sale price. Depending on the cost of the property, the transfer tax could be very large or very small.

The State of Rhode Island does have a real estate transfer tax although it has not been utilized for land banking purposes. Effective use of land banking to acquire large amounts of open space has occurred throughout New England in states like Vermont and Massachusetts in addition to other states. The City should seriously research the use of real estate transfer taxes for land banking purposes. Such a tool, which effectively acquires open space at little or no cost to the public, is a valuable commodity.

\section{Land Trust}

Land trusts have not been prevalent within the City of Cranston. Since land trusts are private organizations, the City has no control over their operation or setup. Cranston could attempt to coordinate efforts to protect land with trusts but because of the small role they have played, it is not anticipated that this option will be very effective.

\section{Overlay District}

Overlay districts are very good methods of protecting natural resources and other precious elements. They usually include regulations which specify site design requirements, and restrict use, density, and lot coverage.

An inventory should be performed to determine the areas within the City, especially the western section, where natural resources that should be protected exist. 
Areas found to contain resources should be targeted for overlay districting, low-density development, or other measures necessary for their protection. These resources might include, groundwater, wetlands, forests, scenic vistas, or other natural features. Cranston currently includes overlay districts within its zoning regulations but their use has not been widespread.

\section{Performance Zoning}

Cranston currently has zoning and subdivision regulations that have been in place for many years. If it were less developed, the adoption and implementation of performance zoning could be more feasible. As such, replacement of the current system of land use regulation with a new one, is not an option. Another consideration is that the Planning Department may not have enough staff to administer the complex system.

Although it is not recommended that the zoning format change, it is important that the document be revised after adoption of the Comprehensive Plan in order to carry out the intentions of the Plan. Also, there is currently additional legislation (Zoning Enabling Act, H-5798 Sub C) that if passed would require all zoning regulations for Rhode Island municipalities to conform to specific guidelines. Any revision of the zoning ordinance should also comply to these guidelines.

\section{$\underline{\text { Planned Unit Development }}$}

Currently one planned unit development district exists in the eastern section of Cranston. In the few years that it has existed a few proposals have surfaced as to what 
to do on the site but none have come to fruition. One problem with a development of this magnitude is that it requires much coordination and financial resources. A project of this type is not recommended for westem cranston because there is no demand for a development of this magnitude. Nor is this type of development consistent with the goals of the community at this time for that section.

\section{Purchase of Development Rights}

Due to the high costs of PDR, the State of Rhode Island is the only entity to have used this technique. Presently, over three hundred acres of land throughout westem Cranston has been purchased by the State through this program. Because of the high costs, it is not recommended that the City uses this approach although it should make a coordinated effort to work with the State and bring to its attention any land which it deems valuable or endangered (the State currently has no funding for this program). Once land is obtained by way of PDR, it is preserved in perpetuity.

\section{Special Permits}

Cranston's zoning regulations already contain a special permitting authority. Those uses that require special permits are specifically outlined in the zoning ordinance for each respective zone. No improvement of this component is recommended. 


\section{Site Plan Review}

Cranston currently does not have site plan regulations in place. This is an integral part of land development regulation and should be implemented. Site plan review should critique development proposals for elements such as: site analysis; natural opportunities/constraints; site and building layout and design; privacy/security; road layout/design; pedestrian and bike paths; parking areas; open space; landscaping; buffering; signs; and lighting. Thresholds should also be specified in order to simplify the application of the regulations. In addition, final approval of conditions should be left to the Planning Commission or the Director to allow for the negotiation of public amenities. The City of East Providence currently possesses a very effective site plan review process which should be studied by the City and used as a guide for future implementation.

\section{Traditional Neighborhood District}

Similar to planned unit development and village development, TND's are very complex, require large amounts of land, and involve many large scale uses. This type of development may be too large or complex for the situation in western Cranston and goals of the community. Although a small scale TND could be implemented, it may attract unwanted commercial or industry to the area. Other design such as village development may be more appropriate for Cranston. 


\section{Transfer of Development Rights}

Transfer of development rights have not been previously utilized in Cranston. It is recommended that this method be used in the future to transfer rights from land in the rural areas of the City to those located in the urban sections, or used within villages, (if implemented), to control densities. Although TDR can be complex, it is very efficient and rural landscape is preserved at no cost to the public. If village development is used, this concept could be especially applicable to regulate densities throughout the project.

\section{Village Development}

This is one of the most recommended techniques that should be implemented in Cranston. Village development will most appropriately achieve the goals of providing housing and small scale community services, preserving open space and the rural landscape, and increase neighborhood unity and social and cultural interaction. Village development can take place on a smaller scale than a PUD or TND and will not attract unwanted commercial or industrial uses if implemented correctly. Because compact residential development of this type requires infrastructure components such as water and sewer services, extensions of current infrastructure will likely occur in the areas that villages are proposed and constructed. Measures will have to be taken to ensure that these improvements do not result in the type of undesirable $1 / 2$ acre standard subdivision development which has occurred in the past.

Implementation may be difficult if many different landowners are involved. Economically speaking, those who own the land that is designated for high density 
development and community services such as in the village center may gain more than those who own the land that will constitute the open space/forested buffer surrounding the village. Those who are apt to get more out of the development will be more supportive than those who are not. Another consideration is that some individuals may not wish to develop their land and may block implementation of a village district. In order for the village concept to work, all land must conform to the design specifications of the zone, and if some areas are not in conformance the village may not be cohesive. Despite these difficulties, the village concept is still the more applicable than some of the other larger, multi-use development concepts like planned unit development and traditional neighborhood districts.

\section{Conclusion}

The City of Cranston, specifically the Planning Department, can utilize some or all of the actions recommended in this chapter to improve the future evolution of the western section and other open areas of the City in which rural landscapes are inherent. Village and cluster development can be successfully implemented in conjunction with land banking, overlay zones and transfer of development rights. Although by themselves they can be effective, in coordination with each other, these techniques can achieve the best results. Other communities similar to Cranston and those of varying densities and character can also utilize these techniques to improve the quality of development and preserve rural landscape. 


\section{REFERENCES}

1.Cranston Planning Commission,Comprehensive Plan, January, 1992. 


\section{H A P T ER FIVE}

Expected Outcomes

\section{Introduction}

Despite the numerous solutions available to communities to solve their land use problems, there are always difficulties in implementing them because of a lack of public or political support. Often times there is resistance when it is recommended that the status quo change or that land use stray from conventional zoning techniques which have been accepted for years. Therefore, when new ideas are introduced to communities, citizens and community leaders are often skeptical.

The key to acceptance is education. Community members must understand what the new ideas are all about. If they are not properly informed, community members cannot make educated decisions about new alternatives, and the result is conformance to the old conventions they are accustomed to, which do not solve the problems the community is facing. Anton Nelessen, Andres Duany, and Randall Arendt are three planners who take three approaches to educating the public officials and residents about new ideas. They have come up with simple, yet innovative ways to educate and inform the public that altematives to conventional zoning not only exist, but that offer a better solution to controlling growth and development in their community. Their general approach is to allow the audience to recognize the inadequacies of conventional methods by comparative analysis, utilizing visual, graphic, and narrative characteristics of each. 


\section{Education Techniques}

Anton Nelessen. Anton Nelessen utilizes the idea of "community preference" to inform to educate individuals about village and hamlet development. He feels that although people live in a conventionally zoned world, they prefer a world made up of small towns and villages. Once people realize that conventional zoning is not giving them what they really want, the acceptance of alternatives is relatively easy.'

Nelessen begins by hosting a show with 250 slides in which has asks that each individual rate attractiveness on a scale from an extremely unpleasant -10 to an extremely attractive +10 . The slides include pictures of standard subdivisions, shopping centers, community services, traditional town centers, open spaces, village greens, and other community land use components.

The outcome of the slide show ratings are always the same. Those slides that represent neotraditional concepts usually score on the more attractive scale, while those that represent conventional zoning are found to be less attractive. The audience proves for themselves that the designs and environments that they prefer are neotraditional and not conventional.

Next, Nelessen asks participants to group together and design their own hamlets based on the attractive elements they saw in the slide presentation. When they are completed the finished products are combined to produce villages. This allows the participants to view neotraditional techniques at varied scales.

Finally, Nelessen makes a strong point with the participants. He stresses that the villages that have just be constructed and all of the characteristics that made them 
attractive to the participants, are illegal. Conventional zoning does not allow this type of development to occur. Therefore, there must be something wrong with it because it does not allow what people prefer.

Andres Duany. Andres Duany prefers the "charette" process to educate a community about the virtues of neotraditionalist methods, primarily traditional neighborhood districts. The charette process attempts to familiarize a community with neotraditional terms and implementation, aspects which usually unfamiliar to the community. Specifically, the charette involves a concentrated effort to solve a problem. ${ }^{2}$ Duany assembles a team of planners, architects, engineers, and other researchers to gather data pertaining to a specific problem facing a community. Over the course of a week the team prepares a master plan that includes a site design and a growth management ordinance. The key to this approach is that the effort is focused on one problem that the entire team is involved with and which completely analyzes and organizes an approach to problem solving. The most recent charette to take place in this area occurred in the city of Providence, Rhode Island in an attempt to solve land use, parking, safety, housing, and urban design problems in the downtown area.

Randall Arendt. Arendt, a planner who primarily lectures to New England communities, uses the best case/worst case scenario method of comparison by allowing the audience to visualize the development of an area by both conventional and alternative methods $^{3}$. By comparing conventional design with a village or cluster development option, it is obvious to onlookers that the latter options offer a more traditional, attractive, 
and open landscape design. Several communities have adopted the open space provisions recommended by the Arendt after having him address their community.

\section{Conclusion}

The likelihood of the City of Cranston encountering resistance to the implementation of new ideas and development patterns is very high. The city has a responsibility to provide housing and community services, preserve the rural landscape, and protect natural resources, goals which may be mutually exclusive. It must first find the most appropriate means to achieve these goals then work with the community for acceptance of them.

This project has recommended that village and cluster development are the most appropriate means to achieve these ends the community seeks. By implementing them, housing is provided that is potentially more affordable to all people, natural resources are

preserved, community services are provided, growth is controlled, infrastructure costs are low, community identity is provided, and rural landscape is protected. If community leaders and residents are informed of the effectiveness of the new methods and the inadequacies of older ones, they are more apt to accept the newer techniques. 


\section{REFERENCES}

1.Nelessen, Anton. Hamlets and Villages in the Neotraditional Forms. New Jersey Environmental Commission, 1989.

2.Duany, Andres. Suburban Sprawl or Livable Neighborhoods. Planners Training Service Symposium on Neotraditional Town Planning, Washington, D.C., 1990.

3.Yaro, Robert D., Arendt, Randall G., Dodson, Harry L., and

Brabec, Elizabeth A. Dealing with Change in the Connecticut River Valley: A Design Manual for Conservation and Development. Center for Rural Massachusetts, Amherst, 1988. 


\section{BIBLIOGRAPHY}

Branch, Mellville C. Comprehensive City Planning, Education and Explanation. American Planning Association Planners Press, Chicago, IL, 1985.

Brower et al. Managing Development in Small Towns. American Planning Association, Chicago,IL.

Central Massachusetts Regional Planning Commission and Metropolitan Area Planning Council. Inventory of Growth Management Techniques. Boston, MA, May 1985.

Cranston City Planning Commission. City of Cranston, Rhode Island Comprehensive Plan. IEP, Inc., Northboro, MA, January 1992.

Daniels, Thomas L. The Purchase of Development Rights, Preserving Agricultural Land and Open Space. Joumal of the American Planning Association, Autumn 1991.

Duany, Andres. Suburban Sprawl or Livable Neighborhoods. Planners Training Service Symposium on Neotraditional Town Planning, Washington, D.C., 1990.

Hughes, James W. Dilemmas of Suburbanization and Growth Controls. The Anals of the American Academy of Political and Social Science. 422, November 1975, pg. 63 1992.

Kupa, John J. Seminar in Ecological Planning, University of Rhode Island, Spring,

Massachusetts Association of Conservation Commissioners. Environmental Handbook for Massachusetts Conservation Commissioners. Tufts University, Medford, MA, 1985.

Metropolitan Area Planning Council. Balanced Growth Manual. Boston, MA, 1978.

Metropolitan Area Planning Council. The Growth Management Catalogue; A Compendium of Growth Management Techniques. Boston, MA, November 1987.

Metropolitan Area Planning Council. Growth Management Techniques. Boston MA, April 1978.

Metropolitan Area Planning Council. Water Resources Protection Techniques. Boston, MA, 1978. 
Nelessen, Anton. Hamlets and Villages in the Neotraditional Forms. New Jersey Environmental Commission, 1989.

Patel, Dinker I. Exurbs: Urban Residential Development in the Countryside. University Press of America, Washington D.C., 1980

Pioneer Valley Planning Commission. Land Tools and Techniques For Successful Managing Growth and Development. Springfield, MA, May 1988.

Pizor, Peter J. Making TDR Work. Joumal of the American Planning Association, Spring 1986.

Planning Magazine. You Don't Have to be Big to Like Performance Zoning. American Planning Association, May 1985, pp.16.

Rahenkanmp, John E. and Hengst, William G. Road Corridor Overlay Zoning for Roadside Enhancement. Urban Land Magazine, May 1988, pp. 11.

Stokes, Samuel N. and Watson, Elizabeth A. Saving America's Countryside, A Guide to Rural Conservation. Johns Hopkins University Press, Baltimore, MD, 1989.

Sutro, Suzanne. Reinventing the Village. American Planning Association Planners Advisory Service, Report Number 430, 1990.

Thomas Planning Services. Growth Management Strategies, Egremont and Lee Massachusetts. Boston, MA, December 1987

Yaro, Robert D., Arendt, Randall G., Dodson, Harry L., and Brabec, Elizabeth A. Dealing with Change in the Connecticut River Valley: A Design Manual for Conservation and Development. Center for Rural Massachusetts, Amherst, 1988.

Zoning News. New Traditionalism in Suburban Design. American Planning Association, June 1989, pp. 1.

Zoning News. Standards for Overlay Districts. American Planning Association, August 1991, pp. 1. 


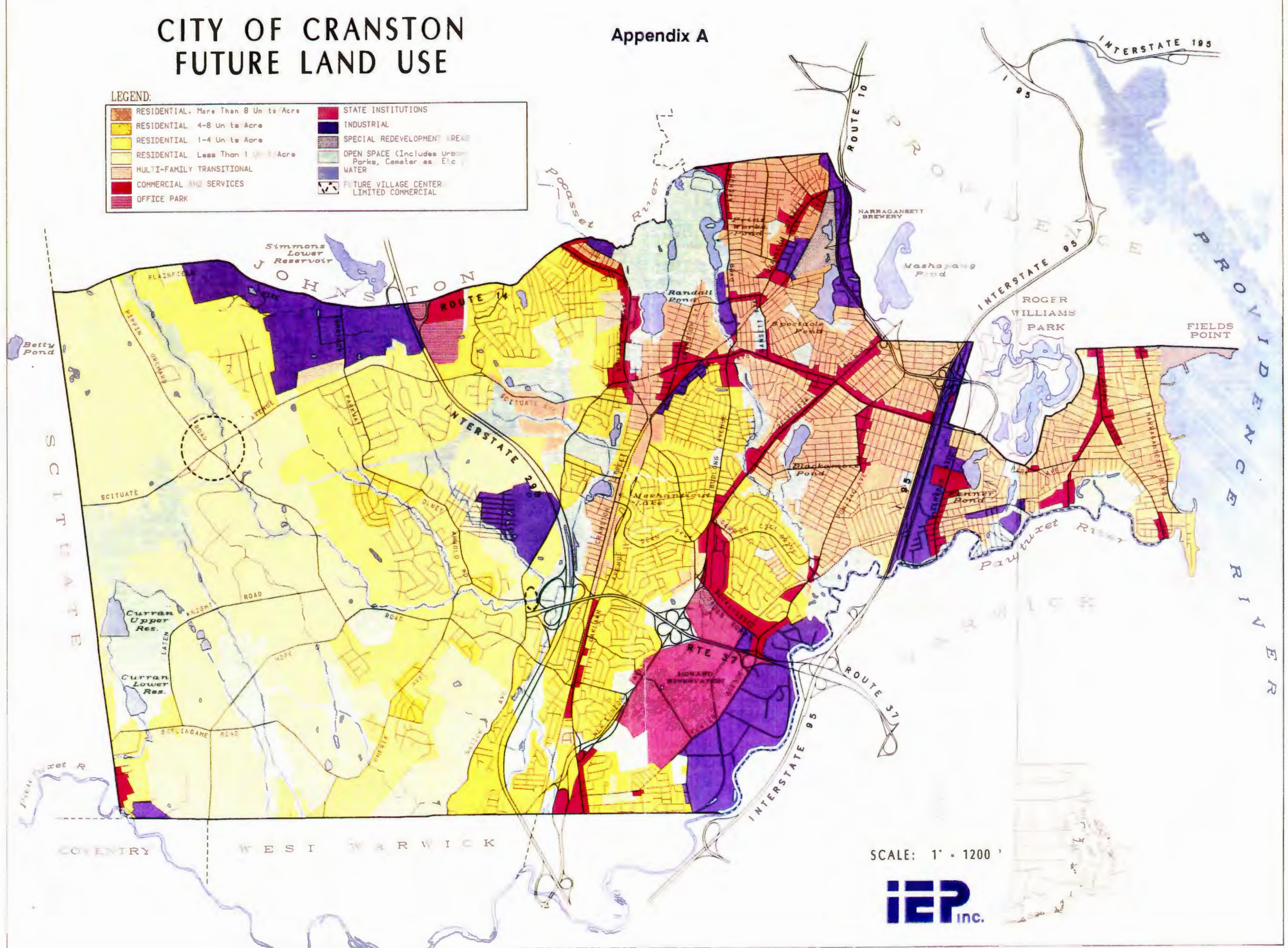

